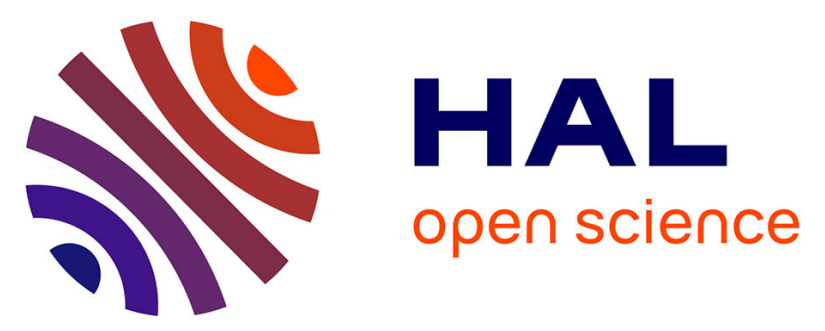

\title{
Effects of bacterial direct-fed microbials and yeast on site and extent of digestion, blood chemistry, and subclinical ruminal acidosis in feedlot cattle
}

\author{
K.A. Beauchemin, W.Z. Yang, Diego Morgavi, G.R. Ghorbani, W. Kautz, \\ J.A.Z. Leedle
}

\section{To cite this version:}

K.A. Beauchemin, W.Z. Yang, Diego Morgavi, G.R. Ghorbani, W. Kautz, et al.. Effects of bacterial direct-fed microbials and yeast on site and extent of digestion, blood chemistry, and subclinical ruminal acidosis in feedlot cattle. Journal of Animal Science, 2003, 81, pp.1628-1640. 10.2527/2003.8161628x . hal-02675787

\section{HAL Id: hal-02675787 \\ https://hal.inrae.fr/hal-02675787}

Submitted on 31 May 2020

HAL is a multi-disciplinary open access archive for the deposit and dissemination of scientific research documents, whether they are published or not. The documents may come from teaching and research institutions in France or abroad, or from public or private research centers.
L'archive ouverte pluridisciplinaire HAL, est destinée au dépôt et à la diffusion de documents scientifiques de niveau recherche, publiés ou non, émanant des établissements d'enseignement et de recherche français ou étrangers, des laboratoires publics ou privés.

\section{다(1)(2)}

Distributed under a Creative Commons Attribution - ShareAlikel 4.0 International 


\title{
Effects of bacterial direct-fed microbials and yeast on site and extent of digestion, blood chemistry, and subclinical ruminal acidosis in feedlot cattle $\mathrm{e}^{1,2}$
}

\author{
K. A. Beauchemin $\uparrow^{3}$, W. Z. Yang $\dagger$, D. P. Morgavi $\dagger^{4}$, G. R. Ghorbani*, and W. Kautz ${ }^{\ddagger}$ \\ and J. A. Z. Leedle
}

$\dagger$ Research Center, Agriculture and Agri-Food Canada, Lethbridge, AB, T1J 4B1, Canada, *Isfahan University of Technology, Isfahan, Iran, and $\ddagger$ Chr. Hansen, Inc., Milwaukee, WI 53214

\begin{abstract}
Two studies were conducted to determine whether a bacterial direct-fed microbial (DFM) alone or with yeast could minimize the risk of acidosis and improve feed utilization in feedlot cattle receiving high-concentrate diets. Eight ruminally cannulated steers, previously adapted to a high-concentrate diet, were used in crossover designs to study the effects of DFM on feed intake, ruminal $\mathrm{pH}$, ruminal fermentation, blood characteristics, site and extent of digestion, and microbial protein synthesis. Steers were provided ad libitum access to a diet containing steam-rolled barley, barley silage, and a protein-mineral supplement (87, 8, and 5\% on a DM basis, respectively). In Exp. 1, treatments were control vs. the lactic-acid producing bacterium Enterococcus faecium EF212 (EF; $6 \times 10^{9}$ $\mathrm{cfu} / \mathrm{d})$. In Exp. 2, treatments were control vs EF $(6 \times$ $10^{9} \mathrm{cfu} / \mathrm{d}$ ) and yeast (Saccharomyces cerevisiae; $6 \times 10^{9}$ $\mathrm{cfu} / \mathrm{d})$. Supplementing feedlot cattle diets with EF in Exp. 1 increased $(P<0.05)$ propionate and $(P<0.05)$ decreased butyrate concentrations, decreased the nadir of ruminal $\mathrm{pH}(P<0.05)$, enhanced the flow of feed $\mathrm{N}$
\end{abstract}

$(P<0.10)$ to the duodenum but reduced that of microbial $\mathrm{N}(P<0.10)$, reduced $(P<0.10)$ intestinal digestion of $\mathrm{NDF}$, and increased $(P<0.10)$ fecal coliform numbers. Other than the increase in propionate concentrations that signify an increase in energy precursors for growth, the other metabolic changes were generally considered to be undesirable. In Exp. 2, providing EF together with yeast abolished most of these undesirable effects. Combining EF with yeast increased the DM digestion of corn grain incubated in sacco, but there were no effects on altering the site or extent of nutrient digestion. The diets used in this study were highly fermentable, and the incidence of subclinical ruminal acidosis, defined as steers with ruminal $\mathrm{pH}$ below 5.5 for prolonged periods of time, was high. Supplementing the diet with EF, with or without yeast, had limited effects on reducing ruminal acidosis. It seems that cattle adapted to high-grain diets are able to maintain relatively high feed intake and high fiber digestion despite low ruminal $\mathrm{pH}$. The Enterococcus faecium bacterium and yeast used in this study were of limited value for feedlot cattle already adapted to high-grain diets.

Key Words: Acidosis, Enterococcus, Microbial Flora, Probiotics, Yeasts

(C2003 American Society of Animal Science. All rights reserved.

J. Anim. Sci. 2003. 81:1628-1640

\section{Introduction}

Direct-fed microbials (DFM), or probiotics, are live, naturally occurring bacterial supplements (Yoon and

\footnotetext{
${ }^{1}$ Lethbridge Research Centre contribution number 387(02090).

${ }^{2}$ The authors thank B. Farr, A. Furtado, R. Wuerfel, K. Andrews, and D. Vedres for their assistance in conducting the experiment and performing laboratory analyses and the staff of the Lethbridge Research Centre metabolism unit for care of the cattle. The financial contributions of Chr. Hansen, Inc. and the Agriculture and Agri-Food Canada Matching Investment Initiative are gratefully acknowledged.

${ }^{3}$ Correspondence: Box 3000 (phone: 403-317-2235; fax: 403-3823156; E-mail: beauchemin@agr.gc.ca).

${ }^{4}$ Current address: Institut National de la Recherche Agronomique (INRA-URH), Centre Clermont-Theix, 631222 Saint-Genès-Chapanelle, France.

Received September 30, 2002.

Accepted February 4, 2003.
}

Stern, 1995). The original concept of feeding bacterial DFM to livestock was based primarily on potentially beneficial postruminal effects, including improved establishment of beneficial gut microflora (Fuller, 1999). However, certain bacterial DFM may also improve ruminal function. Ghorbani et al. (2002) reported that steers receiving both lactate-utilizing Propionibacterium and lactate-producing Enterococcus had higher ruminal concentrations of acetate, and some of the blood variables measured indicated a reduced risk of metabolic acidosis. Although the mode of action of DFM in the rumen is not completely understood, the presence of lactate-producing bacteria is thought to help the ruminal microflora adapt to the presence of lactic acid (Ghorbani et al., 2002), whereas the presence of lactateutilizing bacteria is thought to prevent accumulation of lactate (Nisbet and Martin, 1994; Kung and Hession, 
1995). Nocek et al. (2000) reported decreased risk of acidosis for dairy cows receiving a combination of yeast and lactate-producing bacteria, Lactobacillus and Enterococcus.

There is a growing body of evidence that supplementing diets with yeast (Saccharomyces cerevisiae) increases milk production of dairy cows and weight gain of growing cattle (Yoon and Stern, 1995). Production responses attributed to yeast are usually related to stimulation of cellulolytic and lactate-utilizing bacteria in the rumen, increased fiber digestion, and increased flow of microbial protein from the rumen (Martin and Nisbet, 1992; Newbold et al., 1996), which may be beneficial for feedlot cattle fed high-grain diets.

The objective of this study was to evaluate whether providing Enterococcus faecium, a lactate-producing bacterium, alone or in combination with yeast, to feedlot cattle fed a high-grain diet could decrease the risk of acidosis and improve feed digestion.

\section{Materials and Methods}

\section{Experimental Design and Animals}

Two experiments were conducted: the first used $E n$ terococcus faecium alone, while the second used E. faecium and yeast. Each experiment was conducted as a crossover design with two squares, four steers within each square, two periods and two diets. The squares (groups) within each experiment were run concurrently, and experiments were run consecutively.

Eight cannulated steers were used in both experiments. Steers in the first group were fitted with ruminal cannulas, whereas the steers in the second group were fitted with ruminal and duodenal cannulas. The ruminal cannulas measured $10 \mathrm{~cm}$ in diameter and were constructed of soft plastic (Bar Diamond, Parma, ID). The duodenal cannulas were simple, T-shaped cannulas that were placed proximal to the common bile and pancreatic duct, approximately $10 \mathrm{~cm}$ distal to the pylorus. Surgeries for both groups of animals were completed about 6 mo before starting the experiment. Prior to the start of the adaptation phase of the experiment, Group 1 steers had not been exposed to grain diets, whereas Group 2 had been used previously in a 4-mo study in which a high-grain barley-based diet was fed. Body weight of steers in Groups 1 and 2, respectively, was $484 \pm 58 \mathrm{~kg}$ and $530 \pm 33 \mathrm{~kg}$ at the start of Exp. 1 and $514 \pm 68 \mathrm{~kg}$ and $562 \pm 25 \mathrm{~kg}$ at the start of Exp. 2 .

The length of each period was $3 \mathrm{wk}$, with a 10-d adaptation and an 11-d measurement period. Steers were housed in individual stalls bedded with rubber mats and cared for according to the guidelines of the Canadian Council on Animal Care (1993).

In order to minimize carryover effects from periodto-period, on the last day of Period 1, the rumen of each steer was emptied manually, and the ruminal contents were placed into the rumen of the next steer within the square that was to receive that treatment. Thus, each
Table 1. Ingredient and chemical composition of the total mixed diet (DM basis)

\begin{tabular}{|c|c|}
\hline Item & $\%$ \\
\hline \multicolumn{2}{|l|}{ Ingredient $^{\mathrm{a}}$} \\
\hline Barley silage ${ }^{\mathrm{bc}}$ & 7.94 \\
\hline Barley, stream-rolled ${ }^{\mathrm{d}}$ & 87.13 \\
\hline Barley, ground & 0.97 \\
\hline Canola meal & 1.52 \\
\hline Calcium carbonate & 1.85 \\
\hline Trace mineral/vitamin mix ${ }^{\mathrm{e}}$ & 0.05 \\
\hline Salt & 0.54 \\
\hline \multicolumn{2}{|l|}{ Chemical composition } \\
\hline ME allowed gain, $\mathrm{kg} / \mathrm{d}^{\mathrm{f}}$ & 2.01 \\
\hline $\mathrm{NE}_{\mathrm{g}}, \mathrm{Mcal} / \mathrm{kg}^{\mathrm{f}}$ & 1.17 \\
\hline $\mathrm{NE}_{\mathrm{m}}, \mathrm{Mcal} / \mathrm{kg}^{\mathrm{f}}$ & 1.80 \\
\hline $\mathrm{OM}, \%$ & 94.2 \\
\hline $\mathrm{CP}, \%$ & 12.5 \\
\hline MP allowed gain, $\mathrm{kg} / \mathrm{d}^{\mathrm{f}}$ & 1.53 \\
\hline $\mathrm{NDF}, \%$ & 22.0 \\
\hline Effective NDF, \% & 8.09 \\
\hline $\mathrm{ADF}, \%$ & 10.2 \\
\hline
\end{tabular}

${ }^{\text {a} A l l ~ i n g r e d i e n t s ~ p e l l e t e d, ~ e x c l u d i n g ~ s t e a m-r o l l e d ~ b a r l e y ~ a n d ~ s i l a g e . ~}$

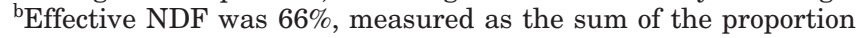
of sample retained on the top $(4.2 \%)$ and bottom $(61.9 \%)$ sieves of the Penn State particle separator.

${ }^{\mathrm{C} C o m p o s i t i o n ~ w a s ~} 37.1 \% \mathrm{DM}, 12.3 \% \mathrm{CP}, 45.8 \% \mathrm{NDF}, 28.3 \% \mathrm{ADF}$, and $4.8 \%$ lignin based on four samples composited by period.

${ }^{\mathrm{d}}$ Processing index measured as the volume weight of the barley after processing (DM basis), expressed as a percentage of its volume weight (DM basis) before processing was $79 \%$.

eSupplied per kilogram of DM of diet: $15 \mathrm{mg}$ of $\mathrm{Cu}, 63 \mathrm{mg}$ of $\mathrm{Zn}$, $27 \mathrm{mg}$ of Mn, $0.65 \mathrm{mg}$ of Io, $0.2 \mathrm{mg}$ of Co, $0.3 \mathrm{mg}$ of Se, 4,200 IU of vitamin $\mathrm{A}, 415 \mathrm{IU}$ of vitamin $\mathrm{D}$, and $13 \mathrm{IU}$ of vitamin $\mathrm{E}$.

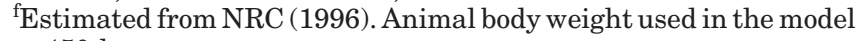
was $450 \mathrm{~kg}$.

steer started the period with ruminal contents corresponding to the same treatment it was fed. At the end of Exp. 1, the ruminal contents from control steers were transferred to control steers in Exp. 2, and ruminal contents from treatment animals were transferred to treatment animals in Exp. 2.

\section{Treatments and Diet}

In Exp. 1, steers received either the control treatment or E. faecium EF212 (EF), and in Exp. 2, steers received either the control treatment or E. faecium EF212 with yeast (EF + Yeast). The treatments were supplied by Chr. Hansen, Inc. (Milwaukee, WI). The viability of the preparation was checked by Chr. Hansen, Inc., prior to starting the experiment. The bacteria and yeast were blended with calcium carbonate to supply $6 \times 10^{8} \mathrm{cfu}$ of bacteria per gram $\left(6 \times 10^{9} \mathrm{cfu} / \mathrm{d}\right)$ and $6 \times 10^{8} \mathrm{cfu}$ of yeast per gram $\left(6 \times 10^{9} \mathrm{cfu} / \mathrm{d}\right)$ when top-dressed onto the diet once daily at the time of feeding $\left(10 \mathrm{~g} \cdot \mathrm{d}^{-1}\right.$. steer $\left.^{-1}\right)$. Steers fed the control diets received only carrier $\left(10 \mathrm{~g} \cdot \mathrm{d}^{-1} \cdot\right.$ steer $\left.^{-1}\right)$.

The experimental diet contained $87 \%$ steam-rolled barley, $8 \%$ whole crop barley silage, and $5 \%$ supplement (DM basis), as shown in Table 1 . The diet was formulated using NRC (1996) to meet or exceed the CP, effective fiber, mineral, and vitamin requirements of cattle 
weighing $450 \mathrm{~kg}$ and gaining $1.5 \mathrm{~kg} / \mathrm{d}$. The diet was prepared daily using a feed mixer. Feed was offered once daily at 0900 for ad libitum intake (at least $10 \%$ orts). Feed offered and refused were recorded daily.

\section{Intakes and Body Weight}

Samples of barley silage, concentrate (comprised of rolled barley grain and pelleted supplement), and diet were collected five times weekly and composited. Dry matter was determined on a portion of each weekly composite feed sample, and the DM contents were used to adjust the silage to concentrate ratio of the diet when necessary. Weekly samples of barley silage, concentrate, and diet were then composited by period and retained for chemical analysis. Samples of orts were collected daily and composited by animal for each period. Samples were dried, and DMI for each steer was calculated based on the feed DM offered and orts DM refused.

The steers were weighed at on the first day of Period 1 and at the end of each period before feeding but before evacuating the rumen.

\section{Ruminal $p H$}

Ruminal $\mathrm{pH}$ was measured continuously for $3 \mathrm{~d}$ of each period on d 14 to 17 using indwelling electrodes. An electrode (model PHCN-37; Omega Engineering, Stamford, CT) was inserted into the rumen of each steer through the cannula. A weight was attached to the electrode to ensure that it remained in the ventral sac. In addition, a protective shield with large openings that allowed ruminal fluid to percolate freely was placed around the electrode to prevent it from coming in contact with the ruminal epithelium. The electrodes were removed from the rumen approximately $1 \mathrm{~h}$ prior to feeding each day and calibrated with $\mathrm{pH} 4.0$ and $\mathrm{pH} 7.0$ standards. Thus, continuous $\mathrm{pH}$ measurements were made for about $23 \mathrm{~h} / \mathrm{d}$. The $\mathrm{pH}$ was measured every 5 $\mathrm{s}$, and an average of these readings was recorded every 15 min using a data logger. Ruminal $\mathrm{pH}$ data were summarized daily for each steer in each period as daily mean $\mathrm{pH}$, maximum and minimum $\mathrm{pH}$, proportion of the measurement period in which $\mathrm{pH}$ was below 5.8 or below 5.5, and area below $\mathrm{pH} 5.8$ or $\mathrm{pH}$ 5.5. The proportion of time during which $\mathrm{pH}$ was below the particular threshold value was calculated using the actual duration that $\mathrm{pH}$ was measured for that animal. The threshold values of 5.5 and 5.8 were chosen because these values have been used previously to indicate subclinical ruminal acidosis (Brown et al. 2000; Ghorbani et al. 2002). The area was calculated by adding the absolute value of negative deviations in $\mathrm{pH}$ from $\mathrm{pH} 5.8$ or 5.5 for each 15-min interval. The number was then expressed as $\mathrm{pH}$ units $\times \mathrm{h}$. The duration that $\mathrm{pH}$ remained below the threshold indicates the duration of subclinical acidosis, while the area between the curve and the $\mathrm{pH}$ threshold indicates the severity of subclinical acidosis.

\section{Ruminal Fermentation}

At 0,6 , and $12 \mathrm{~h}$ after feeding on $\mathrm{d} 18$ and $\mathrm{d} 21$, ruminal contents $(250 \mathrm{~mL}$ per site) were obtained from four sites within the rumen (reticulum, dorsal and ventral sac, and the mat), composited, and strained through a polyester monofilament fabric (Pecap 7-355/ 47, mesh opening-355 $\mu \mathrm{m}$, Tetko Inc., Scarborough, ON, Canada). Five milliliters of filtrate was preserved by adding $1 \mathrm{~mL}$ of $25 \%$ (wt/vol) $\mathrm{HPO}_{3}$ to determine VFA and lactate, and $5 \mathrm{~mL}$ of filtrate was preserved by adding $1 \mathrm{~mL}$ of $1 \%$ (wt/vol) $\mathrm{H}_{2} \mathrm{SO}_{4}$ to determine $\mathrm{NH}_{3}$. The samples were subsequently stored frozen at $-20^{\circ} \mathrm{C}$ until analyses.

\section{Microbiological Enumerations}

At 0,6 , and $12 \mathrm{~h}$ after feeding on d 15 and d 18 , ruminal contents ( $250 \mathrm{~mL}$ per site) were obtained from four sites within the rumen (reticulum, dorsal and ventral sac, and the mat), blended anaerobically under oxygen-free $\mathrm{CO}_{2}$, and strained through a polyester monofilament fabric (Pecap 7-355/47, mesh opening 355$\mu \mathrm{m}$, Tetko Inc. Five milliliters of filtrate was preserved using $1 \mathrm{~mL}$ of methyl green formalin-saline solution for protozoa enumeration (Ogimoto and Imai, 1981). These protozoal samples were stored at room temperature and protected from light until counting. Protozoa were counted with the aid of a hemocytometer chamber. Duplicate preparations of each sample were counted, and if either value differed from the average by more than $10 \%$, the counts were repeated. Blended, strained ruminal contents were serially diluted in $0.1 \%$ (wt/vol) anaerobic buffered peptone. Diluted samples were inoculated $(0.2 \mathrm{~mL} /$ tube $)$ in triplicate into Hungate tubes for enumeration of total ( $10^{-6}$ to $10^{-9}$ dilution), amylolytic $\left(10^{-4}\right.$ to $10^{-7}$ dilution), and lactate-utilizing ( $10^{-3}$ to $10^{-6}$ dilution) bacteria by the roll-tube technique. For enumeration of the total viable bacterial population, medium 10 of Caldwell and Bryant (1966) was used with glucose $(0.1 \% \mathrm{wt} / \mathrm{vol})$, maltose $(0.1 \% \mathrm{wt} / \mathrm{vol})$, cellobiose $(0.1 \% \mathrm{wt} / \mathrm{vol})$, DL-lactic acid solution $(0.085 \% \mathrm{wt} /$ $\mathrm{vol})$, and starch $(0.1 \% \mathrm{wt} / \mathrm{vol})$ added as carbohydrate sources. For enumeration of amylolytic and lactate-utilizing bacteria, a selective carbohydrate agar was used based on medium 10 of Caldwell and Bryant (1966) containing $0.1 \%$ (wt/vol) soluble starch or $50 \mathrm{~m} M$ lactic acid as the main energy source for amylolytic and lactate-utilizing bacteria, respectively.

Fecal samples were obtained from the rectum on $d$ 16 at $0 \mathrm{~h}$ for enumeration of total coliform bacteria. Fecal samples were diluted $\left(10^{-2}\right.$ to $\left.10^{-5}\right)$ in $0.1 \%$ (wt/vol) anaerobic buffered peptone and inoculated in triplicate into Petri dishes, mixed with molten MacConkey agar media (Becton Dickinson Microbiology Systems, Sparks, MD) and allowed to solidify. Colonies were enumerated after $24 \mathrm{~h}$ incubation at $39^{\circ} \mathrm{C}$.

\section{In Sacco Digestion}

To evaluate the potential effects of the treatments on rate and extent of feed digestion, samples of rolled 
corn, rolled barley, and alfalfa hay were incubated in sacco for 0,2 (grain only), 4, 6, 12, 24, 48, and 96 (hay only) h starting on d 14. Samples were incubated in duplicate (triplicate for the final time points) each period in two of the four steers in Group 1.

The rolled grains were used as is, but the hay was dried at $55^{\circ} \mathrm{C}$ for $48 \mathrm{~h}$ and ground through a $4.5-\mathrm{mm}$ screen. Five grams of DM were then weighed into small bags $(10 \times 20 \mathrm{~cm})$ made of monofilament Pecap polyester (pore size-51 $\pm 2 \mu \mathrm{m}$; B. \& S. H. Thompson, Ville MontRoyal, QC, Canada) and heat-sealed. Individual bags were placed in mesh retaining sacs that allowed ruminal fluid to percolate among the bags. The bags were then soaked in warm $\left(39^{\circ} \mathrm{C}\right)$ water for $10 \mathrm{~min}$ and placed in the rumen (except the 0 -h bags). Zero-hour bags were prepared in quadruplicate and incubated for $30 \mathrm{~min}$ in artificial ruminal fluid (Goering and Van Soest, 1970) without the micromineral solution. All bags were removed at the end of the incubation period, machine washed (without the spin cycle) for $10 \mathrm{~min}$ in cold water, and machine rinsed for $3 \mathrm{~min}$. Bags were then manually washed under cold tap water and checked for broken seams. Bags were dried at 55 to $60^{\circ} \mathrm{C}$ for $48 \mathrm{~h}$ and weighed to determine DM disappearance.

Kinetics of DM disappearance in sacco were estimated using the non linear regression procedure of SAS (SAS Inst., Inc., Cary, NC). For each steer, period, and feed (rolled barley grain, rolled corn grain, and ground alfalfa hay), the model proposed by Ørskov and McDonald (1979) and modified by McDonald (1981) to incorporate a lag was fitted to the percentage of DM disappearance as follows:

$$
\mathrm{y}=\mathrm{a}+\mathrm{b}\left(1-\mathrm{e}^{-\mathrm{c}[\mathrm{t}-\mathrm{L}]}\right) \text { for } \mathrm{t}>\mathrm{L}
$$

where $\mathrm{a}=$ soluble fraction $(\%), \mathrm{b}=$ slowly degradable fraction (\%), $\mathrm{c}=$ fractional rate constant at which $\mathrm{b}$ is degraded $(\% / \mathrm{h}), \mathrm{L}=$ lag time $(\mathrm{h})$, and $\mathrm{t}=$ time of incubation (h).

Model parameters were then used to estimate DM disappearance at 12,24 , and $48 \mathrm{~h}$ of incubation for the three feeds.

\section{In Vivo Digestion and Microbial N Synthesis}

Duodenal flow and apparent digestibilities of nutrients in the total tract were determined using $\mathrm{YbCl}_{3}$ (Rhône-Poulenc, Inc., Shelton, CT). Ammonia ${ }^{15} \mathrm{~N}$ $\left(\left[{ }^{15} \mathrm{NH}_{4}\right]_{2} \mathrm{SO}_{4}, 10.6\right.$ atom \% ${ }^{15} \mathrm{~N}$; Isotec, Miamisburg, $\mathrm{OH})$ was used as a ruminal microbial marker. During the last $11 \mathrm{~d}$ of the period, marker solutions were continuously infused into the rumen of steers in Group 2 via the ruminal cannula using an automatic pump. Daily amounts infused were $1.5 \mathrm{~g}$ of $\mathrm{Yb}$ and $180 \mathrm{mg}$ of ${ }^{15} \mathrm{~N}$ dissolved in $550 \mathrm{~mL}$ of water for each animal. Ruminal (from the reticulum, dorsal, and ventral sac; $800 \mathrm{~mL}$ total), duodenal $(300 \mathrm{~mL})$, and fecal samples (100 g) were collected four times daily, every $6 \mathrm{~h}$ moving ahead $1.5 \mathrm{~h}$ each day, for the last $4 \mathrm{~d}$ of the period. This schedule provided 16 representative samples of ruminal, duodenal, and fecal contents taken at 1.5 -h intervals.

Ruminal samples were immediately squeezed through two layers of cheesecloth. Ruminal particles in the retentate were blended ( $400 \mathrm{~g}$ of ruminal particles plus $400 \mathrm{~mL}$ of $0.9 \% \mathrm{NaCl}$ ) in a Waring blender (Waring Products Division, New Hartford, CT) for $1 \mathrm{~min}$ and then squeezed through four layers of cheesecloth. The filtrates obtained by squeezing the ruminal samples and the filtrate obtained from squeezing the blended retentate were combined and centrifuged $(800 \times g$ for $10 \mathrm{~min}$ at $4^{\circ} \mathrm{C}$ ) to remove protozoa and remaining fine feed particles, and the supernatant was centrifuged $\left(27,000 \times \mathrm{g}\right.$ for $30 \mathrm{~min}$ at $\left.4^{\circ} \mathrm{C}\right)$ to obtain a mixed ruminal bacteria pellet. Bacterial pellets, accumulated by steer each period, were freeze-dried and ground using a mortar and pestle. Subsamples of the ground bacterial pellets were further ground to a fine powder using a ball mill (Mixer Mill MM2000; Retsch, Haan, Germany) for determination of $\mathrm{N}$ content and ${ }^{15} \mathrm{~N}$ enrichment.

Duodenal samples were pooled by steer within each period and mixed using a blender (model MX-9100, Toshiba, Tokyo, Japan), freeze-dried, and retained for chemical analysis. Fecal samples were collected from the rectum of each steer. The samples were dried at $55^{\circ} \mathrm{C}$, ground through a $1-\mathrm{mm}$ screen (standard model 4; Arthur H. Thomas Co., Philadelphia, PA), and retained for chemical analyses to determine digestibility.

\section{Blood Chemistry}

On d 17 and 21 of each period, blood samples were taken $5 \mathrm{~h}$ after feeding from the jugular vein of each steer, alternating sides at each collection. The blood was collected in $10-\mathrm{mL}$ vacuum tubes containing $\mathrm{Na}-$ heparin (Vacutainer, No. 6480, green stopper, Becton Dickinson, Franklin Lakes, $\mathrm{NJ}$ ), and blood $\mathrm{pH}$ and $\mathrm{CO}_{2}$ were analyzed within $2 \mathrm{~h}$ by the Lethbridge Regional Hospital (Lethbridge, AB, Canada). The $\mathrm{pH}$ was analyzed on a blood gas analyzer (model IL1715, Instruminaltation Laboratory Co., Lexington, $\mathrm{MA}$ ), and $\mathrm{CO}_{2}$ was determined using a chemistry analyzer (Dimension RXL, Dade Behring Inc., Newark, DE). Packed cell volume was determined by collecting a blood sample in a 7-mL vacuum tube containing $\mathrm{K}_{3}$ EDTA solution (Vacutainer, No. 6450, purple stopper, Becton Dickinson). The blood was transferred to a microhematocrit capillary tube, the end was sealed, and the tube was centrifuged for 6 min with a hematocrit centrifuge and read with a microcapillary reader (model $\mathrm{MH}$, International Equipment Co. Boston, MA). A third sample was collected in a $10-\mathrm{mL}$ vacuum tube containing Na-heparin and silica gel (Vacutainer, No. 366672, green/gray stopper, Becton Dickinson) and centrifuged at 3,000 $\times g$ (model IEC Centra-4B, International Equipment Co., Needham Heights, MA) for 20 min. A subsample (1 mL) of the plasma was centrifuged at $16,000 \times g$ for $2 \mathrm{~min}$ (Spectrafuge 16M, National Labnet Co., Woodbridge, 
$\mathrm{NJ})$ to remove fibrinogen, and the supernatant was used to analyze glucose (slide No. 8130536), lactate dehydrogenase (slide No. 8351082), amylase (slide No. 8208191), $\mathrm{Ca}^{2+}$ (slide No. 8048191), and $\mathrm{Mg}^{2+}$ (slide No. 1080266) using a dry chemistry analyzer (VetTest analyzer, model 8008, IDEXX Lab, Westbrook, ME).

\section{Chemical Analysis}

All chemical analysis was performed on each sample in duplicate, and when the coefficient of variation for the replicate analysis was $>5 \%$, the analysis was repeated. Feed DM was determined by oven drying at $55^{\circ} \mathrm{C}$ for $48 \mathrm{~h}$. Analytical DM content of the samples was determined by drying at $135^{\circ} \mathrm{C}$ for $3 \mathrm{~h}$ (AOAC, 1995), followed by hot weighing. The OM content was calculated as the difference between DM and ash contents (AOAC, 1995; Method 942.05). The NDF and ADF contents were determined by the methods described by Van Soest et al. (1991) with amylase and sodium sulfite used in the NDF procedure. Samples were reground using a ball ground (Mixer Mill MM2000; Retsch, Haan, Germany) for determination of starch and N. The concentration of $\mathrm{CP}(\mathrm{N} \times 6.25)$ in feed was quantified by flash combustion with gas chromatography and thermal conductivity detection (Carlo Erba Instruminalts, Milan, Italy), and ${ }^{15} \mathrm{~N}$ enrichment in duodenal content (i.e., to determine bacteria) was measured by flash combustion with isotope ratio mass spectrometry (VG Isotech, Middlewich, England). Starch was determined by enzymatic digestion as described by Rode et al. (1999).

The processing index of the barley grain was calculated by measuring the volume weight of the barley after processing, expressed as a percentage of its volume weight before processing on a DM basis, to quantify the degree of processing of the barley grain (Yang et al., 2000). The effective fiber content of barley silage was measured as the sum of the proportion of the sample retained on the top and bottom sieves of the Penn State particle separator.

Ruminal VFA were quantified using colonic acid as the internal standard, and gas chromatography (model 5890, Hewlett Parkard, Little Falls, DE) with a capillary column $(30 \mathrm{~m} \times 0.25 \mathrm{~mm}$ i.d., $1 \mu \mathrm{m}$ phase thickness, bonded PEG, Supelco Nukol, Sigma-Aldrich Canada, Oakville, ON) and flame ionization detection. The oven temperature was $100^{\circ} \mathrm{C}$ for $1 \mathrm{~min}$, which was then ramped by $20^{\circ} \mathrm{C} / \mathrm{min}$ to $140^{\circ} \mathrm{C}$, and then by $8^{\circ} \mathrm{C} / \mathrm{min}$ to $200^{\circ} \mathrm{C}$ and held at this temperature for $5 \mathrm{~min}$. The injector temperature was $200^{\circ} \mathrm{C}$, the detector temperature was $250^{\circ} \mathrm{C}$, and the carrier gas was helium. Ruminal $\mathrm{NH}_{3}-\mathrm{N}$ concentration was determined by the salicylate-nitroprusside-hypochlorite method using a flow injection analyzer (Sims et al., 1995). Concentrations of $\mathrm{Yb}$ in the samples were determined using atomic absorption spectrophotometry (AOAC, 1990). Lactic acid was determined by gas chromatography after derivatization with boron trifluoride-methanol as described by Supelco (1998).

\section{Calculations and Statistical Analyses}

Procedures used to calculate site and extent of digestion are explained in further detail by Titgemeyer (1997). Briefly, the flow of DM to the duodenum and the amount of DM excreted in feces were calculated by dividing $\mathrm{Yb}$ infused (1.5 g of $\mathrm{Yb}$ per animal daily) by $\mathrm{Yb}$ concentration (grams of $\mathrm{Yb}$ per kilogram of $\mathrm{DM}$ ) in the duodenal digesta or feces, respectively. Flow of other nutrients to the duodenum or feces was calculated by multiplying DM flow by the concentration of the nutrient in duodenal or fecal DM. Ruminal microbial $\mathrm{N}$ flow to the duodenum for each steer was estimated by the ratio of atom percentage excess of ${ }^{15} \mathrm{~N}$ flow at the duodenum to ${ }^{15} \mathrm{~N}$ atom percentage excess of ruminal bacteria. Organic matter truly digested in the rumen was calculated by first subtracting the amount of $\mathrm{OM}$ contributed by the microbial mass from the flow of $\mathrm{OM}$ to the duodenum.

For each period, means for individual steers were calculated for all variables. Data for microbial counts were converted before analysis using a log transformation. Data were analyzed by experiment with the mixed model procedure of SAS (SAS Inst. Inc.) to account for effects of group (or square), steer within group, period, and treatment. Period within square was not considered in the model because both squares were conducted simultaneously, and thus the effect of period was considered to be the same for both squares. Group, steer within group, and period were considered as random effects and treatment was considered a fixed effect. The restricted maximum likelihood method was used to estimate the variance components and the Kenwardroger method was used to approximate the degrees of freedom. Data for ruminal $\mathrm{pH}$ were summarized by day and then analyzed using the same mixed model but with day included as a repeated measure and using compound symmetry. Similarly, data for VFA within experiment were analyzed by sampling time using a repeated measures model, although means for sampling time were obtained by combining data for both experiments. Treatment effects were declared significant at $P<0.05$, and trends were discussed at $P<0.10$, unless otherwise stated.

\section{Results and Discussion}

\section{Feed Intake and Body Weight}

The diet used in this study was typical of diets used commercially by the feedlot industry in western Canada. Dry matter intake averaged $7.82 \mathrm{~kg}$ throughout the study and was not affected by treatments (Table 2). Steers fed EF were heavier than Contol steers $(P<$ 0.05 ), but the ADG was similar. However, proving yeast with EF had no effect on BW. Because the study was conducted as a metabolism study designed as a Latin square, the growth performance may not reflect the commercial situation. In production studies, there have 
Table 2. Body weight and dry matter intake of steers fed Enterococcus faecium with and without yeast $(n=8)$

\begin{tabular}{|c|c|c|c|c|c|c|}
\hline \multirow[b]{3}{*}{ Item } & \multirow{2}{*}{\multicolumn{3}{|c|}{ Exp. 1}} & \multicolumn{3}{|c|}{ Exp. 2} \\
\hline & & & & & Enterococcus + & \\
\hline & Control & Enterococcus & SE & Control & Yeast & SE \\
\hline \multicolumn{7}{|l|}{ Body weight } \\
\hline Mean for the period, $\mathrm{kg}$ & $519^{\mathrm{b}}$ & $525^{\mathrm{a}}$ & 24 & 552 & 555 & 26 \\
\hline $\mathrm{ADG}, \mathrm{kg} / \mathrm{d}$ & 0.62 & 0.89 & 0.18 & 0.67 & 0.87 & 0.14 \\
\hline DMI, kg/d & 7.78 & 7.78 & 0.49 & 7.95 & 7.75 & 0.45 \\
\hline
\end{tabular}

${ }^{\mathrm{a}, \mathrm{b}}$ Within a row and experiment, means that do not have a common superscript differ $(P<0.05)$.

been some reports of positive effects of bacterial DFM on milk production of dairy cows (Ware et al., 1988) and weight gain of steers (Swinney-Floyd et al., 1999; Galyean et al., 2000; Rust et al., 2000); however, many of these studies have not been published in scientific peer-reviewed journals. Furthermore, many differences exist among bacterial species and strains used as DFM, making it difficult to make comparisons with the literature.

\section{Ruminal $p H$}

The diets used in this study were highly fermentable, and the incidence of subclinical ruminal acidosis was high. We considered subclinical ruminal acidosis to occur when ruminal $\mathrm{pH}$ remained below 5.5 in a steer for more than $50 \%$ of the time on one of the days of measurement. In Exp. 1, six of the eight steers in Period 1 , and five of the eight steers in Period 2, experienced subclinical ruminal acidosis. In Exp. 2, five steers experienced subclinical ruminal acidosis in Period 1, and four in Period 2. The $\mathrm{pH}$ values recorded in Exp. 1 during the evaluation of $\mathrm{EF}$ were lower than those recorded in Exp. 2 during the evaluation of EF + Yeast (Table 3). This indicates that there was increased adaptation of the cattle to these highly fermentable diets over time. The ruminal $\mathrm{pH}$ conditions in which $\mathrm{EF}$ was evaluated were harsher than the conditions in which
$\mathrm{EF}+$ Yeast was evaluated. The mean $\mathrm{pH}$ values (5.68 to 5.74) reported in Exp. 2 are similar to the range of 5.69 to 5.72 reported previously by Ghorbani et al. (2002), but lower than the range of 5.79 to 6.06 reported by Beauchemin et al. (2001) for feedlot cattle fed a similar high-concentrate barley-based diet. Thus, the $\mathrm{pH}$ values reported in Exp. 1 were lower than previously reported for feedlot cattle fed barley-based diets possibly because four of the steers had not been exposed to high-concentrate diets before starting the adaptation phase of this study. In commercial feedlots, cattle are fed backgrounding diets that contain 25 to $40 \%$ grain (DM basis) for several months before receiving highgrain finishing diets. Thus, they are adapted slowly to grain.

The risk of acidosis in this study decreased as time progressed. Steers in Exp. 1 had a ruminal $\mathrm{pH}$ below 5.8 for about $74 \%$ of the time, and below 5.5 for about $55 \%$ of the time, whereas steers in Exp. 2 had a ruminal $\mathrm{pH}$ below 5.8 for about $57 \%$ of the day and below 5.5 for about $39 \%$ of the day (Table 3). Because the diet was the same in both experiments, it appears that the $\mathrm{pH}$ increased, and acidosis decreased, as time progressed and the animals adapted to this high-grain diet.

Treatments had no effect on decreasing acidosis, and, in fact, $\mathrm{EF}$ alone may have exacerbated the problem. Although there was no effect of DFM on mean ruminal pH (Exp. 1: 5.53; Exp. 2: 5.71; Table 3), or maximum

Table 3. Ruminal $\mathrm{pH}$ of steers fed Enterococcus faecium with or without yeast $(\mathrm{n}=8)$

\begin{tabular}{|c|c|c|c|c|c|c|}
\hline \multirow[b]{3}{*}{ Item } & \multirow{2}{*}{\multicolumn{3}{|c|}{ Exp. 1}} & \multicolumn{3}{|c|}{ Exp. 2} \\
\hline & & & & & Enterococcus + & \\
\hline & Control & Enterococcus & $\mathrm{SE}$ & Control & Yeast & $\mathrm{SE}$ \\
\hline Mean & 5.56 & 5.50 & 0.10 & 5.68 & 5.74 & 0.10 \\
\hline Minimum & $5.15^{\mathrm{a}}$ & $5.03^{\mathrm{b}}$ & 0.06 & 5.18 & 5.25 & 0.12 \\
\hline Maximum & 6.21 & 6.33 & 0.10 & 6.40 & 6.40 & 0.07 \\
\hline $\begin{array}{l}\text { Proportion of day } \\
\mathrm{pH}<5.8, \%\end{array}$ & 73.5 & 74.6 & 7.5 & 61.4 & 53.2 & 8.9 \\
\hline $\begin{array}{l}\text { Area }<\mathrm{pH} 5.8, \\
\mathrm{pH} \times \mathrm{h} \\
\text { Proportion of dav }\end{array}$ & 8.5 & 10.1 & 1.5 & 6.1 & 5.8 & 1.5 \\
\hline $\begin{array}{l}\mathrm{pH}<5.5, \% \\
\text { Area }<\text { pH 5.5 }\end{array}$ & 50.1 & 59.5 & 9.6 & 40.4 & 36.8 & 8.7 \\
\hline $\mathrm{pH} \times \mathrm{h}$ & 3.1 & 4.4 & 0.9 & 2.5 & 2.6 & 0.9 \\
\hline
\end{tabular}

${ }^{\mathrm{a}, \mathrm{b}}$ Within a row and experiment, means that do not have a common superscript $\operatorname{differ}(P<0.05)$. 
Table 4. Characteristics of ruminal fermentation in steers fed Enterococcus faecium with or without yeast $(\mathrm{n}=8)$

\begin{tabular}{|c|c|c|c|c|c|c|c|c|c|c|}
\hline \multirow[b]{2}{*}{ Item } & \multicolumn{3}{|c|}{ Exp. 1} & \multicolumn{3}{|c|}{ Exp. 2} & \multicolumn{4}{|c|}{ Time after feeding, $\mathrm{h}$} \\
\hline & Control & Enterococcus & $\mathrm{SE}$ & Control & Yeast & $\mathrm{SE}$ & 0 & 6 & 12 & $\mathrm{SE}$ \\
\hline Total, $\mathrm{m} M$ & 105.9 & 108.4 & 3.1 & 109.0 & 108.9 & 3.6 & $104.7^{\mathrm{b}}$ & $111.0^{\mathrm{a}}$ & $108.5^{\mathrm{ab}}$ & 3.7 \\
\hline Acetate (A), mol/100 mol & 52.7 & 48.9 & 2.3 & 51.6 & 52.8 & 1.6 & 51.7 & 51.4 & 51.5 & 1.7 \\
\hline Propionate (P), mol/100 mol & $25.4^{\mathrm{b}}$ & $33.1^{\mathrm{a}}$ & 3.1 & 27.6 & 28.2 & 2.8 & $27.5^{\mathrm{b}}$ & $29.3^{\mathrm{a}}$ & $28.7^{\mathrm{ab}}$ & 2.1 \\
\hline Valerate, $\mathrm{mol} / 100 \mathrm{~mol}$ & 2.3 & 1.8 & 0.6 & 2.1 & 1.8 & 0.2 & $2.1^{\mathrm{a}}$ & $1.9^{\mathrm{b}}$ & $1.8^{\mathrm{b}}$ & 0.2 \\
\hline Isovalerate, $\mathrm{mol} / 100 \mathrm{~mol}$ & 2.1 & 1.7 & 0.2 & 1.9 & 2.1 & 0.2 & $2.1^{\mathrm{a}}$ & $1.9^{\mathrm{b}}$ & $1.9^{\mathrm{b}}$ & 0.3 \\
\hline Caproic, mol/100 mol & 0.56 & 0.61 & 0.12 & 0.39 & 0.31 & 0.16 & 0.44 & 0.48 & 0.48 & 0.10 \\
\hline $\mathrm{A}: \mathrm{P}$ & $2.46^{\mathrm{c}}$ & $1.66^{\mathrm{d}}$ & 0.39 & 2.17 & 2.06 & 0.28 & $2.17^{\mathrm{a}}$ & $2.02^{\mathrm{b}}$ & $2.08^{\mathrm{ab}}$ & 0.24 \\
\hline Lactate, $\mathrm{m} M$ & $\mathrm{ND}^{\mathrm{e}}$ & ND & & ND & ND & ND & ND & ND & ND & \\
\hline $\mathrm{NH}_{3} \mathrm{~N}, \mathrm{mg} / \mathrm{L}$ & 6.38 & 5.39 & 1.35 & 11.45 & 10.69 & 1.82 & $12.49^{\mathrm{a}}$ & $6.33^{\mathrm{b}}$ & $6.62^{\mathrm{b}}$ & 1.72 \\
\hline
\end{tabular}

${ }^{\mathrm{a}, \mathrm{b}}$ Within a row and experiment, means that do not have a common superscript differ $(P<0.05)$.

${ }^{\mathrm{c}, \mathrm{d}}$ Within a row and experiment, means that do not have a common superscript differ $(P<0.10)$.

${ }^{\mathrm{e}} \mathrm{ND}=$ not detectable.

$\mathrm{pH}$, lowest $\mathrm{pH}$ was lower $(P<0.05)$ for steers receiving EF than for Control steers. There was no effect of treatment on the proportion of time or area below $\mathrm{pH} 5.8$ or 5.5. The results of the current study do not confirm the findings of some other studies in which yeast or DFM based on lactic acid-utilizing bacteria have been used. In those studies, use of DFM decreased the risk of acidosis. Supplementing dairy diets with yeast decreased the drop in ruminal $\mathrm{pH}$ following meals in the study by Williams et al. (1991). Huffman et al. (1992) reported that steers receiving Lactobacillus acidophilus had reduced time that $\mathrm{pH}$ was below 6.0. Nocek et al. (2000) reported daily low $\mathrm{pH}$ was higher, and area under $\mathrm{pH}$ 5.5 was lower, for dairy cows receiving Enterococcus and Lactobacillus. It should be noted that the incidence of subclinical ruminal acidosis was more severe in the present study than in those previous studies. The lack of effect of bacterial DFM on preventing subclinical ruminal acidosis observed in this study confirms the lack of effect on ruminal $\mathrm{pH}$ reported previously for feedlot cattle fed high-grain diets supplemented with mixtures of lactic acid-producing and lactic acid-utilizing bacteria (Kim et al., 2000; Ghorbani et al., 2002). However, in view of the observed difference in ruminal $\mathrm{pH}$ conditions between Exp. 1 and Exp. 2, it is questionable whether a crossover design, even with ruminal emptying, is appropriate methodology for assessing biologically active compounds such as DFM. As there was a significant effect of day on most of the ruminal $\mathrm{pH}$ variables, it is clear that $\mathrm{pH}$ should be measured over several days, as previously reported by Ghorbani et al. (2002).

\section{Ruminal Fermentation}

Low ruminal $\mathrm{pH}$ was due to the accumulation of VFA rather than lactate (Table 4), which is typical for adapted steers (Hristov et al., 2001; Ghorbani et al., 2002). Ruminal concentrations of lactate were ex- tremely low and below the level of detection $(<1 \mathrm{~m} M)$. There was no effect of the treatments on total concentration of VFA, which averaged $108 \mathrm{~m} M$. However, supplementing the diet with EF increased $(P<0.05)$ the proportion of propionate and, consequently, decreased ( $P$ $<0.10$ ) the proportion of butyrate in ruminal fluid compared with the control. These results are consistent with the expectation that supplemental EF stimulate the presence of lactic acid-utilizing bacteria, which produce propionate. Similarly, Kim et al. (2000) reported increased propionate concentrations in steers fed $L$. plantarum, another lactic acid-producing bacterium. In Exp. 2, however, providing yeast with EF negated any effects on propionate proportion. It is not clear whether the lack of effect of EF in the presence of yeast was attributed directly to the yeast or to the fact that the ruminal $\mathrm{pH}$ was higher during Exp. 2 compared with Exp. 1.

As a result of a higher propionate concentration, the acetate:propionate ratio tended to decrease $(P<0.10)$ with EF supplementation, whereas EF + Yeast had no effect on acetate:propionate ratio (Table 4). Other than a decrease $(P<0.05)$ in isobutyrate proportion for steers fed EF + Yeast, the treatments had no effect on other individual VFA proportions or concentration of $\mathrm{NH}_{3}$.

Time after feeding had a significant effect on concentrations of total VFA, most individual VFA proportions, and concentration of $\mathrm{NH}_{3}$ as expected (Table 4). In general, differences were noted between prefeeding $(0 \mathrm{~h})$ and postfeeding $(6,12 \mathrm{~h})$ sampling times, but no differences occurred between 6 and $12 \mathrm{~h}$ postfeeding. Prefeeding, total concentration of VFA was lower, proportions of propionate were lower, proportions of butyrate, isobutyrate, valerate, and isovalerate were higher, acetate:propionate ratio was higher, and $\mathrm{NH}_{3}$ concentrations were higher compared with postfeeding.

\section{Microorganisms}

Protozoal numbers were high (Table 5), confirming previous studies with feedlot cattle fed high-grain diets 
Table 5. Bacterial and protozoal numbers in the ruminal fluid and feces of steers fed Enterococcus faecium with or without yeast $(\mathrm{n}=8)^{\mathrm{a}}$

\begin{tabular}{|c|c|c|c|c|c|c|}
\hline \multirow[b]{3}{*}{ Item } & \multirow{2}{*}{\multicolumn{3}{|c|}{ Exp. 1}} & \multicolumn{3}{|c|}{ Exp. 2} \\
\hline & & & & & Enterococcus + & \\
\hline & Control & Enterococcus & $\mathrm{SE}$ & Control & Yeast & SE \\
\hline \multicolumn{7}{|l|}{ Ruminal fluid } \\
\hline Lactate-utilizing bacteria $\left(\times 10^{7}\right), \mathrm{cfu} / \mathrm{mL}$ & 4.30 & 6.80 & 1.55 & 2.60 & 2.21 & 0.57 \\
\hline Amylolytic bacteria $\left(\times 10^{8}\right), \mathrm{cfu} / \mathrm{mL}$ & 3.91 & 2.49 & 2.08 & 3.66 & 4.78 & 1.40 \\
\hline Total bacteria $\left(\times 10^{10}\right), \mathrm{cfu} / \mathrm{mL}$ & 3.77 & 6.20 & 1.35 & 2.51 & 2.60 & 0.32 \\
\hline Protozoa $\left(\times 10^{6}\right)$, cells $/ \mathrm{mL}$ & 1.24 & 0.77 & 0.32 & 1.38 & 1.39 & 0.22 \\
\hline \multicolumn{7}{|l|}{ Feces } \\
\hline Coliforms $\left(\times 10^{6}\right), \mathrm{cfu} / \mathrm{g}$ & $3.8^{\mathrm{c}}$ & $16.9^{\mathrm{b}}$ & 7.4 & 5.3 & 8.7 & 5.9 \\
\hline
\end{tabular}

${ }^{a}$ Data were log transformed prior to statistical analysis.

${ }^{\mathrm{b}, \mathrm{c}}$ Within a row and experiment, means that do not have a common superscript $\operatorname{differ}(P<0.10)$.

(Hristov et al., 2001; Ghorbani et al., 2002). Most of the protozoal populations were identified as Entodinium. Supplementing the diet with EF tended to decrease $(P$ $<0.15)$ protozoal numbers, which is considered undesirable in terms of preventing acidosis because ruminal protozoa, especially Entodinium, play a critical role in utilizing lactic acid in the rumen (Newbold et al., 1987). The decrease in protozoal numbers with EF supplementation contrasts with the results of Van Koevering et al. (1994) who reported that including lactobacillus cultures in the diet prolonged retention of protozoa. The decrease in protozoal numbers with supplementation of EF was also opposite to the increase in protozoal numbers observed in our previous study (Ghorbani et al., 2002) for steers receiving Propionibacterium, which converts lactate and glucose to acetate and propionate. In the present study, the effect of EF on lowering protozoal numbers was not apparent when diets were also supplemented with yeast.

Treatments had no effects on lactate-utilizing bacteria, amylolytic bacteria, or total bacterial numbers (Table 5). This result was somewhat surprising because both $\mathrm{EF}$ and yeast were expected to increase the presence of lactate-utilizing bacteria.

The number of fecal coliform bacteria tended to $(P<$ 0.10) increase with EF supplementation indicating a postruminal effect. This effect was negated when yeast was provided. The reasons for this undesirable effect of EF on fecal coliforms are not clear and need to be evaluated in further experiments. It is possible that increased numbers of fecal coliform bacteria in cattle fed EF was the result of increased colon acidification, which may have occurred as a result of lower minimum ruminal pH. Diez-Gonzalez et al. (1998) reported that decreased colon $\mathrm{pH}$, which corresponded to lower ruminal $\mathrm{pH}$ as a result of feeding higher grain diets, resulted in an increase in fecal coliform numbers.

\section{In Sacco Digestion}

In sacco digestion of feedstuffs was affected by treatments (Table 6). In general, providing EF alone negatively affected the in sacco digestion of corn grain, bar- ley grain, and alfalfa hay. In contrast, providing EF with yeast generally improved the digestion of these substrates.

For corn, EF alone decreased 12-h $(P<0.05), 24-\mathrm{h}(P$ $<0.05)$, and 48 -h $(P<0.10)$ disappearance, but $\mathrm{EF}+$ Yeast increased $(P<0.10) 24$-h and 48 -h disappearance (Table 6). Furthermore, EF decreased $(P<0.05)$ the size of the degradable fraction, whereas $\mathrm{EF}+$ Yeast increased $(P<0.05)$ it as well as tended to decrease $(P<0.10)$ the rate of digestion. For barley, EF alone decreased $(P<0.05)$ the size of the degradable fraction and the 48-h $(P<0.05)$ disappearance. The negative effect of EF on barley digestion was negated when EF was provided with yeast. For alfalfa hay, EF alone decreased $(P<0.05)$ 24-h disappearance, but this effect was not evident when $\mathrm{EF}$ was provided together with yeast. However, EF + Yeast decreased $(P<0.05)$ the digestion rate and tended $(P<0.10)$ to increase the size of the potentially digestible fraction.

\section{In Vivo Digestion and Microbial N Synthesis}

Supplementation with EF, alone or with yeast, had no effect on total tract digestibility of DM, but tended $(P<0.10)$ to decrease OM digestibility (Table 7). Mean total-tract digestibility of DM and OM during the study was $73.5 \%$ and $76 \%$, respectively, which is similar to previously reported values for barley-based feedlot diets (Beauchemin et al., 2001). Fifty-four percent of the $\mathrm{DM}$ and $\mathrm{OM}$ ingested was digested in the rumen with no effect due to treatments. These values are in agreement with the range of 47 to $63 \%$ for $\mathrm{OM}$ ruminal digestion presented previously for barley-based diets (Beauchemin et al., 2001). A slightly higher ruminal OM digestibility (62 to 66\%) was reported by Zinn (1993) compared to the present study, probably due to the use of readily digestible ingredients such as molasses (8\% of dietary DM).

Starch was almost completely digested (98\%) in the total tract due to extensive digestion in the rumen (Table 8 ). About $83 \%$ of the starch ingested was digested in the rumen, which would account for the high total VFA concentrations and low ruminal $\mathrm{pH}$ values ob- 
Table 6. In sacco digestion kinetics of corn grain, barley grain, and alfalfa hay in steers fed Enterococcus faecium with or without yeast $(\mathrm{n}=2)$

\begin{tabular}{|c|c|c|c|c|c|c|}
\hline \multirow[b]{3}{*}{ Feedstuff } & \multirow{2}{*}{\multicolumn{3}{|c|}{ Exp. 1}} & \multicolumn{3}{|c|}{ Exp. 2} \\
\hline & & & & & Enterococcus + & \\
\hline & Control & Entercoccus & $\mathrm{SE}$ & Control & Yeast & $\mathrm{SE}$ \\
\hline \multicolumn{7}{|l|}{ Corn } \\
\hline Soluble fraction (A), \% & 15.8 & 15.9 & 0.7 & 15.2 & 15.3 & 0.1 \\
\hline Degradable fraction (B), \% & $51.5^{\mathrm{c}}$ & $36.9^{\mathrm{b}}$ & 12.8 & $38.7^{\mathrm{c}}$ & $52.7^{\mathrm{b}}$ & 1.4 \\
\hline Degradation rate (c), $\%$ & 0.054 & 0.072 & 0.032 & $0.060^{\mathrm{d}}$ & $0.048^{\mathrm{e}}$ & 0.002 \\
\hline Lag, h & 0.3 & 0 & 0.2 & 0.7 & 0.9 & 0.6 \\
\hline 12-h disappearance ${ }^{\mathrm{a}}$ & $35.9^{\mathrm{b}}$ & $34.0^{\mathrm{c}}$ & 1.2 & 34.1 & 37.0 & 0.6 \\
\hline 24-h disappearance ${ }^{\mathrm{a}}$ & $46.9^{\mathrm{b}}$ & $42.1^{\mathrm{c}}$ & 1.2 & $44.2^{\mathrm{e}}$ & $50.5^{\mathrm{d}}$ & 0.5 \\
\hline 48-h disappearance ${ }^{\mathrm{a}}$ & $57.5^{\mathrm{d}}$ & $48.6^{\mathrm{e}}$ & 6.5 & $51.5^{\mathrm{e}}$ & $62.4^{\mathrm{d}}$ & 1.1 \\
\hline \multicolumn{7}{|l|}{ Barley } \\
\hline Soluble fraction (A), \% & 14.5 & 13.4 & 1.1 & 14.1 & 13.0 & 0.9 \\
\hline Degradable fraction (B), \% & $58.6^{\mathrm{b}}$ & $45.6^{\mathrm{c}}$ & 6.8 & 50.2 & 53.7 & 6.5 \\
\hline Degradation rate (c), \% & 0.066 & 0.105 & 0.018 & 0.110 & 0.083 & 0.028 \\
\hline Lag, h & 0 & 0 & 0 & 2.0 & 0 & 0.6 \\
\hline 12-h disappearance ${ }^{\mathrm{a}}$ & 46.0 & 45.5 & 3.1 & 45.2 & 46.8 & 2.2 \\
\hline 24-h disappearance ${ }^{a}$ & 60.5 & 54.7 & 4.3 & 57.5 & 59.3 & 2.5 \\
\hline 48-h disappearance ${ }^{\mathrm{a}}$ & $70.4^{\mathrm{b}}$ & $58.5^{\mathrm{c}}$ & 6.2 & 63.2 & 65.6 & 5.3 \\
\hline \multicolumn{7}{|l|}{ Alfalfa hay } \\
\hline Soluble fraction (A), \% & 32.1 & 32.5 & 0.3 & 32.1 & 32.4 & 0.2 \\
\hline Degradable fraction (B), \% & 36.3 & 31.0 & 2.8 & $31.6^{\mathrm{d}}$ & $34.7^{\mathrm{e}}$ & 2.6 \\
\hline Degradation rate (c), \% & 0.045 & 0.045 & 0.002 & $0.054^{\mathrm{b}}$ & $0.048^{\mathrm{c}}$ & 0.001 \\
\hline Lag, h & 1.1 & 0.1 & 0.4 & 2.5 & 0.9 & 0.7 \\
\hline 12-h disappearance ${ }^{\mathrm{a}}$ & 46.2 & 45.2 & 0.9 & 44.9 & 46.6 & 0.6 \\
\hline 24-h disappearance ${ }^{\mathrm{a}}$ & $55.5^{\mathrm{b}}$ & $52.7^{\mathrm{c}}$ & 1.7 & 53.9 & 55.6 & 1.4 \\
\hline 48-h disappearance ${ }^{\mathrm{a}}$ & 64.0 & 59.8 & 2.4 & 61.0 & 63.5 & 2.2 \\
\hline
\end{tabular}

${ }^{a}$ Estimated using the equation: DM disappearance $=\mathrm{A}+\mathrm{B} *\left(1-\mathrm{e}^{-\mathrm{c}[\mathrm{t}-\mathrm{lag}]}\right)$.

${ }^{\mathrm{b}, \mathrm{c}}$ Within a row and experiment, means that do not have a common superscript differ $(P<0.05)$.

${ }^{\mathrm{d}, \mathrm{e}}$ Within a row and experiment, means that do not have a common superscript differ $(P<0.10)$.

Table 7. Intake, duodenal flow, and site and extent of digestion of DM and $\mathrm{OM}$ in steers fed Enterococcus faecium with and without yeast ${ }^{\mathrm{a}}$

\begin{tabular}{|c|c|c|c|c|c|c|}
\hline \multirow[b]{3}{*}{ Item } & \multirow{2}{*}{\multicolumn{3}{|c|}{ Exp. 1}} & \multicolumn{3}{|c|}{ Exp. 2} \\
\hline & & & & & Enterococcus + & \\
\hline & Control & Enterococcus & $\mathrm{SE}$ & Control & Yeast & $\mathrm{SE}$ \\
\hline \multicolumn{7}{|l|}{ DM } \\
\hline Intake (digestion phase) & 8.32 & 8.24 & 0.18 & 8.37 & 8.46 & 0.24 \\
\hline Duodenal flow, kg/d & 5.55 & 5.43 & 0.36 & 5.64 & 5.88 & 0.34 \\
\hline \multicolumn{7}{|l|}{ Digestibility, $\%$ of intake } \\
\hline Ruminal & 57.5 & 55.5 & 4.4 & 53.0 & 51.7 & 2.2 \\
\hline Intestine & 41.5 & 39.0 & 4.5 & 40.6 & 42.7 & 3.8 \\
\hline Total tract & 74.7 & 73.2 & 2.2 & 73.2 & 73.2 & 1.6 \\
\hline \multicolumn{7}{|l|}{$\mathrm{OM}$} \\
\hline Intake, kg/d & 7.94 & 7.84 & 0.18 & 7.75 & 7.81 & 0.24 \\
\hline Duodenal flow, kg/d & & & & & & \\
\hline Total & 4.47 & 4.44 & 0.32 & 4.62 & 4.80 & 0.16 \\
\hline Microbial & 1.10 & 0.95 & 0.13 & 0.97 & 1.04 & 0.08 \\
\hline \multicolumn{7}{|l|}{ Digestibility, \% of intake } \\
\hline Ruminal $^{\mathrm{b}}$ & 57.5 & 55.5 & 4.4 & 53.0 & 51.7 & 2.2 \\
\hline \multicolumn{7}{|l|}{ Intestine } \\
\hline Total $\mathrm{OM}^{\mathrm{c}}$ & 34.8 & 33.2 & 4.1 & 35.2 & 37.2 & 2.8 \\
\hline Feed OM ${ }^{\mathrm{d}}$ & 21.0 & 21.1 & 4.1 & 22.7 & 24.0 & 3.0 \\
\hline Total tract & $78.5^{\mathrm{e}}$ & $76.6^{\mathrm{f}}$ & 2.4 & 75.6 & 75.7 & 1.7 \\
\hline
\end{tabular}

${ }^{\mathrm{a}}$ Measured in four duodenally cannulated steers.

${ }^{\mathrm{b}}$ Corrected for microbial OM.

'Includes feed and microbial components.

${ }^{\mathrm{d}}$ Calculated as the difference between total tract and ruminal digestion.

e,fWithin a row and experiment, means that do not have a common superscript differ $(P<0.10)$. 
Table 8. Intake, duodenal flow, and site and extent of digestion of starch and fiber in steers fed Enterococcus faecium with and without yeast ${ }^{\mathrm{a}}$

\begin{tabular}{|c|c|c|c|c|c|c|}
\hline \multirow[b]{3}{*}{ Item } & \multirow{2}{*}{\multicolumn{3}{|c|}{ Exp. 1}} & \multicolumn{3}{|c|}{ Exp. 2} \\
\hline & & & & & Enterococcus + & \\
\hline & Control & Enterococcus & $\mathrm{SE}$ & Control & Yeast & $\mathrm{SE}$ \\
\hline \multicolumn{7}{|l|}{ Starch } \\
\hline Intake, kg/d & 3.88 & 3.84 & 0.12 & 3.75 & 3.79 & 0.26 \\
\hline Duodenal flow, kg/d & 0.58 & 0.68 & 0.21 & 0.68 & 0.65 & 0.10 \\
\hline \multicolumn{7}{|c|}{ Digestibility, $\%$ of intake } \\
\hline Ruminal & 84.9 & 82.2 & 5.9 & 81.9 & 82.9 & 27 \\
\hline Intestine & 13.6 & 16.3 & 5.1 & 15.8 & 14.9 & 3.0 \\
\hline Total tract & 98.5 & 98.5 & 0.8 & 97.7 & 97.8 & 0.6 \\
\hline \multicolumn{7}{|l|}{$\mathrm{NDF}$} \\
\hline Intake, kg/d & 2.55 & 2.55 & 0.26 & 2.49 & 2.49 & 0.11 \\
\hline Duodenal flow, kg/d & 1.33 & 1.17 & 0.15 & 1.30 & 1.40 & 0.09 \\
\hline \multicolumn{7}{|c|}{ Digestibility, \% of intake } \\
\hline Ruminal & 47.4 & 53.9 & 7.0 & 47.8 & 43.6 & 2.5 \\
\hline Intestine & $10.1^{\mathrm{d}}$ & $0.1^{\mathrm{e}}$ & 6.3 & 5.4 & 7.5 & 3.9 \\
\hline Total tract & 57.5 & 54.0 & 8.7 & 53.1 & 51.1 & 4.0 \\
\hline \multicolumn{7}{|l|}{$\mathrm{ADF}$} \\
\hline Intake, kg/d & 0.86 & 0.87 & 1.02 & $0.91^{\mathrm{e}}$ & $0.93^{\mathrm{d}}$ & 0.05 \\
\hline Duodenal flow, kg/d & 0.64 & 0.60 & 4.9 & $0.65^{\mathrm{c}}$ & $0.71^{\mathrm{b}}$ & 0.07 \\
\hline \multicolumn{7}{|c|}{ Digestibility, $\%$ of intake } \\
\hline Ruminal & 25.9 & 30.9 & 5.2 & $29.6^{\mathrm{b}}$ & $23.5^{\mathrm{c}}$ & 4.7 \\
\hline Intestine & 5.3 & 0.1 & 6.7 & 5.5 & 9.2 & 6.4 \\
\hline Total tract & 31.2 & 30.9 & 3.9 & 35.1 & 32.7 & 5.3 \\
\hline
\end{tabular}

${ }^{a}$ Measured in four duodenally cannulated steers.

${ }^{\mathrm{b}, \mathrm{c}}$ Within a row and experiment, means that do not have a common superscript $\operatorname{differ}(P<0.05)$.

${ }^{\mathrm{d}, \mathrm{e}}$ Within a row and experiment, means that do not have a common superscript differ $(P<0.10)$.

served in this study. Treatments had no effect on site or extent of starch digestion.

Total tract digestibility of NDF and ADF averaged 54 and $32 \%$, respectively during the study, with no effect of treatment (Table 8). About $48 \%$ of the NDF ingested and $27 \%$ of the ADF ingested was digested in the rumen. Thus, despite the low ruminal $\mathrm{pH}$ of the steers in this experiment, ruminal and total tract digestion of fiber remained high. Feeding EF + Yeast decreased $(P<0.05)$ ruminal ADF digestibility, and, consequently, duodenal flow of ADF increased $(P<0.05)$, although EF + Yeast had no effects on NDF digestion. The reason for decreased ruminal digestion of $\mathrm{ADF}$ as a result of feeding EF + Yeast is uncertain. Supplementing diets with $\mathrm{EF}$ alone tended $(P<0.10)$ to lower intestinal digestion of NDF, but this was not the case for steers fed EF + Yeast. The reason for decreased intestinal digestion of fiber for steers receiving $\mathrm{EF}$ is not clear but may be related to the lower nadir ruminal pH in Exp. 1.

Intake of $\mathrm{N}$ and flow of nonammonia $\mathrm{N}$ from the rumen were similar for all treatments (Table 9). However, the composition of the nonammonia $\mathrm{N}$ flow differed between steers fed control and those fed EF. Feeding EF tended $(P<0.10)$ to decrease the flow of microbial $\mathrm{N}$ from the ruminal but $(P<0.10)$ increase the flow of feed $\mathrm{N}$. Decreased flow of microbial $\mathrm{N}$ from the rumen resulted from the numerical decrease in efficiency of microbial $\mathrm{N}$ synthesis, measured as grams of microbial $\mathrm{N}$ per kilogram of OM digested in the ruminal, because
$\mathrm{OM}$ intake and ruminal digestion were similar for both diets. Decreased microbial N synthesis was opposite to expectations, based on the fact that the EF treatment numerically decreased protozoal numbers by $38 \%$. Protozoa contribute to recycling of $\mathrm{N}$ in the rumen and decreasing protozoal numbers is expected to increase efficiency of protein utilization (Jouany, 1996; Koenig et al., 2000). Increased flow of feed $\mathrm{N}$ from the rumen was the result of decreased $(P<0.10)$ ruminal digestion of feed $\mathrm{N}$. This decrease in ruminal digestion of feed $\mathrm{N}$ caused by EF supplementation confirms the results for DM observed in sacco (Table 6). These results indicate that the EF supplement shifted the ruminal environment in a manner similar to that observed with ionophore supplementation: EF increased propionate concentrations, decreased proteolytic activity, and reduced protozoal numbers (Bergen and Bates, 1984).

Providing EF + Yeast negated all effects of EF on $\mathrm{N}$ metabolism (Table 9). However, supplementation with yeast failed to increase the bacterial population in the rumen, alter ruminal digestibility, or change the flow of microbial $\mathrm{N}$ from the rumen, unlike in some other studies (Newbold et al., 1996; Yoon and Stern, 1996). Yoon and Stern (1996) reported for dairy cows that yeast culture increased ruminal $\mathrm{OM}$ and $\mathrm{CP}$ digestion and decreased $\mathrm{OM}$ and $\mathrm{N}$ flow to the duodenum.

\section{Blood Chemistry}

Enterococcus faecium, with or without yeast, had no effect on any of the blood variables measured (Table 
Table 9. Intake and metabolism of $\mathrm{N}$ in the digestive tract of steers fed Enterococcus faecium with and without yeast ${ }^{a}$

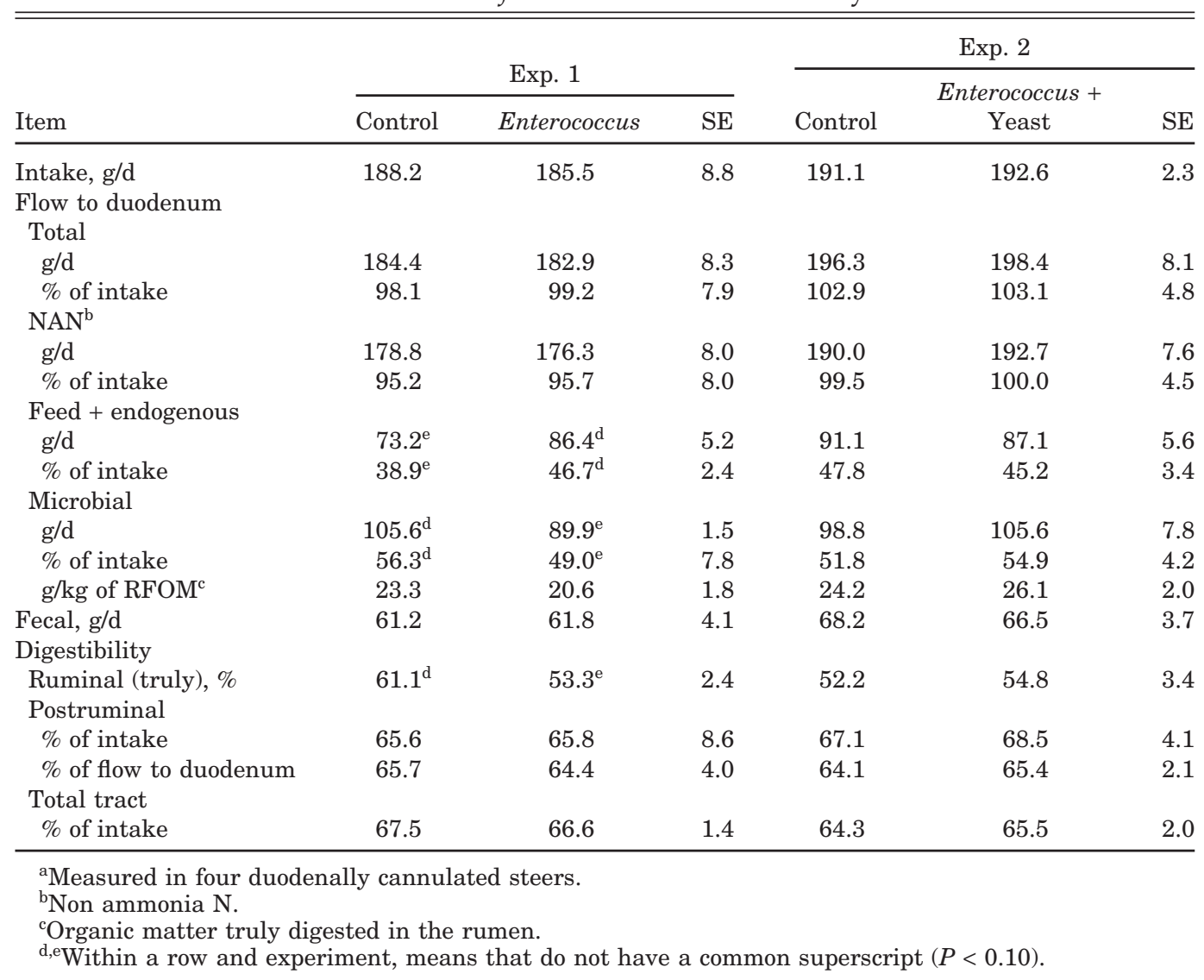

10). The lack of effect of DFM treatments on blood $\mathrm{pH}$ was expected, because the acid-base balance in blood is highly regulated, and blood is saturated with bicarbonate (Owens et al., 1998). Thus, blood pH rarely fluctuates.

In a previous study in which $E$. faecium was provided together with Propionibacterium to feedlot steers, a trend towards decreased concentration of blood $\mathrm{CO}_{2}$ was observed (Ghorbani et al., 2002). Lower concentration of $\mathrm{CO}_{2}$ is indicative of reduced risk of metabolic acidosis (Brown et al., 2000). During metabolic acidosis the concentration of blood $\mathrm{CO}_{2}$ increases due to the reduction of the blood bicarbonate ion (Owens et al., 1998). Effects of bacterial DFM on blood $\mathrm{CO}_{2}$ observed previously were not confirmed by the present study in which EF alone was evaluated.

In addition, previously reported (Ghorbani et al., 2002 ) beneficial effects of feeding a combination of $E$. faecium with Propionibacterium on lowering blood lactate dehydrogenase concentrations of steers were not confirmed in this study for EF or EF + Yeast. Decreased blood lactate dehydrogenase concentration reflects the

Table 10. Blood variables for steers fed Enterococcus faecium with or without yeast $(n=8)$

\begin{tabular}{|c|c|c|c|c|c|c|}
\hline \multirow[b]{3}{*}{ Variable } & \multirow{2}{*}{\multicolumn{3}{|c|}{ Exp. 1}} & \multicolumn{3}{|c|}{ Exp. 2} \\
\hline & & & & & Enterococcus + & \\
\hline & Control & Enterococcus & $\mathrm{SE}$ & Control & Yeast & $\mathrm{SE}$ \\
\hline Blood pH & 7.38 & 7.38 & 0.02 & 7.39 & 7.39 & 0.01 \\
\hline $\mathrm{CO}_{2}, \mathrm{mEq} / \mathrm{L}$ & 25.56 & 26.19 & 1.02 & 25.88 & 26.69 & 0.61 \\
\hline $\mathrm{PCV}, \%^{\mathrm{a}}$ & 32.86 & 33.34 & 1.67 & 31.58 & 31.9 & 1.64 \\
\hline Glucose, mg/L & 1.02 & 1.03 & 0.02 & 0.97 & 0.99 & 0.03 \\
\hline $\mathrm{LDH}$, units/L $\mathrm{L}^{\mathrm{b}}$ & 8,109 & 8,393 & 535 & 8,108 & 8,021 & 568 \\
\hline Amylase, units/L & 40.25 & 37.94 & 2.14 & 45.06 & 44.50 & 3.34 \\
\hline $\mathrm{Ca}^{2+}, \mathrm{mg} / \mathrm{L}$ & 92.32 & 91.84 & 0.96 & 91.23 & 90.11 & 1.01 \\
\hline $\mathrm{Mg}^{2+}, \mathrm{mg} / \mathrm{L}$ & 22.99 & 23.34 & 0.36 & 23.82 & 23.57 & 0.33 \\
\hline
\end{tabular}

apacked cell volume.

${ }^{\mathrm{b}}$ Lactate dehydrogenase. 
reduced need to metabolize lactate from tissue metabolism and absorption from the digestive tract (Owens et al., 1998). Thus, decreased lactate dehydrogenase concentration reflects a reduced risk of acidosis. Lack of effect of DFM in this study on blood lactate dehydrogenase is consistent with the very low concentrations of lactate in ruminal fluid (Table 4), although tissue lactate levels were not measured.

Lack of treatment effects on packed cell volume is consistent with the lack of effects on packed cell volume observed previously using $E$. faecium with Propionibacterium (Ghorbani et al., 2002). The blood cations Na, $\mathrm{K}$, and $\mathrm{Mg}$ usually decrease during acute acidosis, while blood glucose and amylase activity increase (Owens et al., 1998; Brown et al. 2000). Although $\mathrm{K}$ was not measured in this study, the lack of effect of treatments on $\mathrm{Ca}, \mathrm{Mg}$, and amylase further confirms that the DFM studied had little effect on mitigating the effects of subclinical ruminal acidosis.

In summary, supplementing feedlot cattle diets with the lactic-acid producing bacterium $E$. faecium caused small shifts in the microbial ecosystem that led to increased propionate and decreased butyrate concentrations, decreased nadir ruminal $\mathrm{pH}$, a change in the composition of nonammonia $\mathrm{N}$ flowing to the duodenum, reduced intestinal digestion of NDF, and increased numbers of fecal coliforms. The increase in propionate concentrations indicates an increase in energy precursors that would likely benefit growing cattle. However, the other metabolic changes are generally considered to be undesirable. Providing EF together with yeast eliminated the undesirable effects due to feeding EF, but there was little advantage in feeding the combined DFM compared with the Control.

The changes associated with supplementing diets with both bacteria and yeast were marginal with no effects on ruminal fermentation or ruminal microorganisms. Although the DM digestion of corn grain incubated in sacco increased, increased digestion of the barley-based diet was not confirmed by measurements of site or extent of nutrient digestion within the steers. It is possible that the $\mathrm{EF}+$ Yeast treatment would have been more effective had a corn-based diet been fed to the steers. The potentially beneficial effects of yeast may be diet and strain dependent. Newbold et al. (1995) reported differences in the metabolic effect of various strains of yeast, even when they were grown in an identical manner. This study supports the prior evidence that the beneficial effects of yeast are greater in foragebased diets than in high-concentrate diets (Sullivan and Martin, 1999).

Treatments had no effect on decreasing acidosis, and in fact providing $E$. faecium alone may have exacerbated acidosis as indicated by a lower nadir $\mathrm{pH}$. Despite the low ruminal $\mathrm{pH}$ and high incidence of subclinical ruminal acidosis caused by feeding highly fermentable grain-based diets, ruminal and total tract digestion of $\mathrm{OM}$ and fiber remained high. For feedlot cattle accustomed to consuming high-grain diets, there was limited value in providing bacterial DFM based on $E$. faecium bacterium, even when provided along with yeast.

\section{Implications}

Although bacterial direct-fed microbials might have the potential to improve feed utilization of feedlot cattle, the choice of bacterial species is crucial to formulating an effective product. The lactic acid-producing bacterium Enterococcus faecium used in this study was shown to be metabolically active and caused small shifts in the microbial ecosystem of feedlot cattle fed highgrain diets. However, these changes in digestive function were generally viewed to be of minor importance or even undesirable. Furthermore, supplementing the diet of feedlot cattle with Enterococcus faecium, with or without yeast, had limited effects on reducing ruminal acidosis or improving feed utilization. Thus, based on our results, a direct-fed microbial based on Enterococcus faecium, with or without yeast, is of limited value for feedlot cattle adapted to high-grain diets. However, the possibility that supplemental Enterococcus faecium bacteria may benefit nonadapted cattle, such as newly received cattle, cannot be excluded.

\section{Literature Cited}

AOAC. 1995. Official Methods of Analysis. 16th ed. Assoc. Offic. Anal. Chem., Arlington, VA.

Beauchemin, K. A., W. Z. Yang, and L. M. Rode. 2001. Effects of barley grain processing on the site and extent of digestion of beef. J. Anim. Sci. 79:1925-1936.

Bergen, W. G., and D. B. Bates. 1984. Ionophores: Their effect on production efficiency and mode of action. J. Anim. Sci. 58:1465-1483.

Brown, M. S., C. R. Krehbiel, M. L. Galyean, M. D. Remmenga, J. P. Peters, B. Hibbard, J. Robinson, and W. M. Moseley. 2000. Evaluation of models of acute and subacute acidosis on dry matter intake, ruminal fermentation, blood chemistry, and endocrine profiles of beef steers. J. Anim. Sci. 78:3155-3168.

Caldwell, D. R., and M. P. Bryant. 1966. Medium without ruminal fluid for nonselective enumeration and isolation of ruminal bacteria. Appl. Microbiol. 14:794-801.

Canadian Council on Animal Care. 1993. Guide to the care and use of experimental animals. vol. 1. 2nd ed. CCAC, Ottawa, ON, Canada.

Diez-Gonzalez, F., T. R. Callaway, M. G. Kizoulis, and J. Russell. 1998. Grain feeding and the dissemination of acid-resistant Escherichia coli from cattle. Science 281:1666-1668.

Fuller, R. 1999. Probiotics for farm animals. Page 15 in ProbioticsA Critical Review. G. W. Tannocka (ed.) Horizon Scientific Press, Wymondham, England.

Galyean, M. L., G. A. Nunnery, P. J. Defoor, G. B. Salyer, and C. H. Parsons. 2000. Effects of live cultures of Lactobacillus acidophilus (Strains 45 and 51) and Propionibacterium freudenreichii PF-24 on performance and carcass characteristics of finishing beef steers. Available: http://www.asft.ttu.edu/burnettcenter/ progressreports/bc8.pdf. Accessed April 30, 2001.

Ghorbani, G. R., D. P. Morgavi, K. A. Beauchemin, and J. A. Z. Leedle. 2002. Effects of bacterial direct-fed microbials on ruminal fermentation, blood variables, and the microbial populations of feedlot cattle. J. Anim. Sci. 80:1977-1985.

Goering, H. K., and P. J. Van Soest. 1970. Forage Fiber Analyses (Apparatus, Reagents, Procedures, and Some Applications). Agric. Handbook No. 379. ARS-USDA, Washington, DC. 
Hristov, A. N., M. Ivan, L. M. Rode, and T. A. McAllister. 2001. Fermentation characteristics and ruminal ciliate protozoal populations in cattle fed medium- or high-concentrate barley-based diets. J. Anim. Sci. 79:515-524.

Huffman, R. P., K. K. Karges, T. J. Klopfenstein, R. A. Stock, R. A. Britton, and L. D. Roth. 1992. The effect of Lactobacillus acidophilus on subacute ruminal acidosis. J. Anim. Sci. 70(Suppl. 1):87. (Abstr.)

Jouany, J. P. 1996. Effect of ruminal protozoa on nitrogen utilization by ruminants. J. Nutr. 126:1335S-1346S.

Kim, S. W., D. G. Standford, H. Roman-Rosario, M. T. Yokoyama, and S. R. Rust. 2000. Potential use of Propionibacterium acidipropionici, strain DH42, as a direct-fed microbial for cattle. J. Anim. Sci. 78 (Suppl. 1):1225(Abstr.).

Koenig, K. M., C. J. Newbold, F. M. McIntosh, and L. M. Rode. 2000. Effects of protozoa on bacterial nitrogen recycling in the ruminal. J. Anim. Sci. 78:2431-2445.

Kung, L., Jr., and A. O. Hession. 1995. Preventing in vitro lactate accumulation in ruminal fermentation by inoculation with $\mathrm{Meg}$ asphaera elsdenii. J. Anim. Sci. 73:250-256.

Martin, S. A., and D. J. Nisbet. 1992. Effect of direct-fed microbials on ruminal microbial fermentation. J. Dairy Sci. 75:1736-1744.

McDonald, I. 1981. A revised model for the estimation of protein degradability in the ruminal. J. Agric. Sci. 96:251-252.

Newbold, C. J., A. G. Williams, and D. G. Chamberlin. 1987. The in vitro metabolism of D,L-lactic acid by ruminal microorganisms. J. Sci. Food Agric. 38:9-18.

Newbold, C. J., R. J. Wallace, X. B. Chen, and F. M. McIntosh. 1995. Different strains of Saccharomyces cervisiae differ in their effects on ruminal bacterial numbers in vitro and in sheep. J. Anim. Sci. 73:1811-1818.

Newbold, C. J., R. J. Wallace, and F. M. McIntosh. 1996. Mode of action of the yeast Saccharomyces cerevisiae as a feed additive for ruminants. Brit. J. Nutr. 76:249-261.

Nisbet, D. J., and S. A. Martin. 1994. Factors affecting L-lactate utilization by Selenomonas ruminantium. J. Anim. Sci. 72: $1355-1361$.

Nocek, J. E., W. P. Kautz, J. A. Z. Leedle, and J. G. Allman. 2000. Altering diurnal $\mathrm{pH}$ and in situ digestion in dairy cows with ruminal supplementation of direct-fed microbials (DFM) and yeast. J. Dairy Sci. 83(Suppl. 1):1242.(Absr.)

NRC. 1996. Nutrient Requirements of Beef Cattle. 7th rev. ed. N. Acad. Press, Washington, DC.

Ogimoto, K., and S. Imai. 1981. Page 158 in Atlas of Ruminal Microbiology. Japan Scientific Societies Press, Tokyo.

Ørskov, E. R., and I. McDonald. 1979. The estimation of protein degradability in the ruminal from incubation measurements weighted according to rate of passage. J. Agric. Sci. (Camb.) 92:499-503.

Owens, F. N., D. S. Secrist, W. J. Hill, and D. R. Gill. 1998. Acidosis in cattle: A review. J. Anim. Sci. 76:275-286.
Rode, L. M., W. Z. Yang, and K. A. Beauchemin. 1999. Fibrolytic enzyme supplements for dairy cows in early lactation. J. Dairy Sci. 82: 2121-2126.

Rust, S. R., K. Metz, and D. R. Ware. 2000. Effect of Bovamine ruminal culture on the performance and carcass characteristics of feedlot steers. Pages 22-26 in Mich. Agric. Exp. Stn. Beef Cattle, Sheep and Forage Sys. Res. Dem. Rep. No. 569.

Sims, G. K., T. R. Ellsworth, and R. L. Mulvaney. 1995. Microscale determinations of inorganic nitrogen in water and soil extracts. Commun. Soil Sci. Plant Anal. 26:303-316.

Sullivan, H. M., and S. A. Martin. 1999. Effects of Saccharomyces cervisiae culture on in vitro mixed ruminal microorganism fermentation. J. Dairy Sci. 82:2011-2016.

Supelco. 1998. Analyzing fatty acids by packed column gas chromatography. Pages 5-7 in Sigma-Aldrich Corp., Bulletin 856, Bellefonte, PA.

Swinney-Floyd, D., B. A. Gardiner, F. N. Owens, T. Rehberger, and T. Parrott. 1999. Effects of inoculation with either strain P-63 alone or in combination with Lactobacillus acidophilus LA53545 on performance of feedlot cattle. J. Anim. Sci. 77(Suppl. 1): 77. (Abstr.)

Titgemeyer, E. C. 1997. Design and interpretation of nutrient digestion studies. J. Anim. Sci. 75:2235-2247.

Van Koevering, M. T., F. N. Owens, D. S. Secrist, R. H. Anderson, and R. E. Herman. 1994. Cobactin II for feedlot steers. Page 83 in Abstracts of ASAS/ADSA Midwestern Section.

Van Soest, P. J., J. B. Robertson, and B. A. Lewis. 1991. Methods for dietary fiber, neutral detergent fiber and non-starch polysaccharide in relation to animal nutrition. J. Dairy Sci. 74:35833597.

Ware, D. R., P. L. Read, and E. T. Manfredi. 1988. Lactation performance of two large dairy herds fed Lactobacillus acidophilus strain BT 1386 in a switchback experiment. J. Dairy Sci. 71(Suppl. 1):219. (Abstr.)

Williams, P. E. V., C. A. G. Tait, G. M. Innes, and C. J. Newbold. 1991. Effects of the inclusion of yeast culture (Saccharomyces cerevisiae plus growth medium) in the diet of dairy cows on milk yield and forage degradation and fermentation patterns in the ruminal of steers. J. Anim. Sci. 69:3016-3026.

Yang, W. Z., K. A. Beauchemin, and L. M. Rode. 2000. Effects of barley grain processing on extent of digestion and milk production of lactating cows. J. Dairy Sci. 83:554-568.

Yoon, I. K., and M. D. Stern. 1995. Influence of direct-fed microbials on ruminal fermentation and performance of ruminants: A review. Aust. Asian J. Anim. Sci. 8:533-555.

Yoon, I. K., and M. D. Stern. 1996. Effects of Saccharomyces cerevisiae and Aspergillus oryzae cultures on ruminal fermentation in dairy cows. J. Dairy Sci. 79:411-417.

Zinn, R. A. 1993. Influence of processing on the comparative feeding value of barley for feedlot cattle. J. Anim. Sci. 71:3-10. 